\title{
WSPÓŁPRACA PLACÓWEK OPIEKUŃCZO-WYCHOWAWCZYCH Z INSTYTUCJAMI EDUKACYJNYMI
}

\section{COOPERATION BETWEEN EDUCATIONAL CARE FACILITIES AND EDUCATIONAL INSTITUTIONS}

\author{
Marzena Ruszkowska ${ }^{1(\mathrm{~A}, \mathrm{~B}, \mathrm{C}, \mathrm{D}, \mathrm{E}, \mathrm{F})}$, Beata Wołosiuk $\mathbf{k}^{1(\mathrm{C}, \mathrm{E})}$, \\ Sebastian Sobczuk ${ }^{1(C, D)}$, Piotr Zdunkiewicz ${ }^{1(B, C)}$
}

${ }^{1}$ Zakład Pedagogiki, Państwowa Szkoła Wyższa im. Papieża Jana Pawła II w Białej Podlaskiej

Ruszkowska, M., Wołosiuk, B., Sobczuk, S., Zdunkiewicz, P. (2018). Współpraca placówek opiekuńczo-wychowawczych z instytucjami edukacyjnymi. Rozprawy Społeczne, 12(2), 51-56. https://doi.org/10.29316/rs.2018.17

Wkład autorów:

A. Zaplanowanie badań

B. Zebranie danych

C. Dane - analiza i statystyki

D. Interpretacja danych

E. Przygotowanie artykułu

F. Wyszukiwanie i analiza

literatury

G. Zebranie funduszy

\begin{abstract}
Streszczenie
Wstęp. Działania wychowawcze podejmowane w rodzinie wpływają w istotny sposób na dalsze życie i funkcjonowanie dziecka. Rodzice nie muszą sami dźwigać odpowiedzialności za wychowanie dzieci, powinni być wspomagani przez osoby i grupy społeczne, zaangażowane w działania edukacyjne. W przypadku kiedy dziecko przebywa w placówce opiekuńczo-wychowawczej, to wychowawcy pełnią te same role co rodzice biologiczni dziecka.

Materiał i metody. Badania dla potrzeb niniejszej publikacji realizowano w Placówkach Opiekuńczo-Wychowawczych na terenie powiatu bialskiego. Celem badań było ustalenie czy placówki opiekuńczo-wychowawcze współpracują z instytucjami edukacyjnymi, tj. szkoła, poradnia psychologiczno-pedagogiczna, terapeuci, logopedzi i inni specjaliści, na czym ta współpraca polega, jakie przybiera formy.

Wyniki. Wśród form współpracy wymienia sie różnego rodzaju kontakty z nauczycielami, tj.: wywiadówki, kontakt indywidualny, kontakt telefoniczny, mailowy, kontakt przez dziennik elektroniczny. Ponadto dyrektorzy szkół, wychowawcy klasowi i pedagodzy szkolni uczestniczą w posiedzeniach zespołu ds. okresowej oceny sytuacji dziecka, odbywających się na terenie placówki przynajmniej dwa razy w roku.

Wnioski. O współpracy pomiędzy placówką opiekuńczo-wychowawczą a placówkami oświatowymi decydują głównie: wiek podopiecznych, zachowanie podopiecznych i problemy przez nich wskazywane oraz usytuowanie placówki przez nich zamieszkiwanej.
\end{abstract}

Słowa kluczowe: placówka opiekuńczo-wychowawcza, instytucje edukacyjne, współpraca

\begin{abstract}
Summary
Introduction. Child upbringing and parenting activities significantly affect the child's further existence and functioning. Parents do not have to bear the responsibility for raising children themselves, they should be supported by individuals and social groups involved in educational activities. In the case where the child is in a care and education centre, the educators perform the same roles as biological parents of the child.

Material and method. The research for the purposes of this publication was carried out in the Nursing and Education Centres in Bialski district. The purpose of the research was to determine whether the care and educational institutions cooperate with educational institutions, i.e. school, psychological and pedagogical clinic, therapists, speech therapists and other specialists, as well as what kind of co-operation is involved.

Results. There are different types of communication with teachers recognised as forms of cooperation, i.e. parent-teacher meetings, individual contact, contact via phone, e-mail, electronic school reports. Moreover, school headmasters, tutors and pedagogues participate in the meetings of the group for the interim assessment of children's situation held at the care and education institution at least two times a year.

Conclusions. The decisive factors for cooperation between a care and education institution and an educational institution include: the age of pupils, their behaviour and the problems they point to as well as the location of the institution where they live.
\end{abstract}

Keywords: care and education institution, educational institutions, cooperation

Adres korespondencyjny: Marzena Ruszkowska, Państwowa Szkoła Wyższa im. Papieża Jana Pawła II, Zakład Pedagogiki, ul. Sidorska 102, 21-500 Biała Podlaska, e-mail:r-ska.marzena@wp.pl, tel.: 833449911

Copyright by: Państwowa Szkoła Wyższa im. Papieża Jana Pawła II w Białej Podlaskiej, Marzena Ruszkowska, Beata Wołosiuk, Sebastian Sobczuk, Piotr Zdunkiewicz

Czasopismo Open Access, wszystkie artykuły udostępniane są na mocy licencji Creative Commons Uznanie autorstwa-użycie niekomercyjne-na tych samych warunkach 4.0 Międzynarodowe (CC BY-NC-SA 4.0, http://creativecommons.org/licenses/by-nc-sa/4.0/). 


\section{Wstęp}

Działania wychowawcze podejmowane $\mathrm{w}$ rodzinie wpływają w istotny sposób na dalsze życie i funkcjonowanie dziecka. Rodzice nie muszą sami dźwigać odpowiedzialności za wychowanie i edukację własnych dzieci, powinni być wspomagani przez osoby i grupy społeczne, zaangażowane w działania edukacyjne. Wiele osób ma swój udział w kształceniu i wychowaniu dzieci, które rozwijają się w konkretnym środowisku. Osiąganie przez dziecko dojrzałości nie byłoby możliwe bez wsparcia ze strony instytucji edukacyjnych. Zarówno rodzina jak i szkoła mają wpływ na zaspokajanie potrzeb rozwoju bio-psycho-socjo-kulturalnego młodego człowieka, jednak ,jest on korzystny tylko wówczas, gdy te środowiska są skłonne do współpracy, takiej w której nauczyciele i rodzice utrzymuja ze sobą częste i bliskie kontakty" (Smykowska, 2008, s. 19).

Jak wynika z Europejskiej Karty Praw i Obowiązków Rodziców mają oni prawo wpływać na politykę oświatową realizowaną w szkołach ich dzieci. Rodzice mają obowiązek osobiście włączać się w życie szkół i stanowić istotną część społeczności lokalnej (Europejska Karta Praw i Obowiązków Rodziców).

Podstawowe zadania opiekuńczo-wychowawcze wobec dziecka w rodzinie najczęściej pełnione są przez rodziców biologicznych. W sytuacjach dysfunkcjonalności rodziny, szczególnie w przypadku różnego rodzaju zaniedbań ze strony rodziców, niejednokrotnie dochodzi do umieszczenia dziecka poza domem rodzinnym. Zadaniem państwa jest organizacja opieki zastępczej. Obecnie obowiązujące regulacje prawne wymieniają formy pieczy instytucjonalnej i rodzinnej (Ustawa o wspieraniu rodziny i systemie pieczy zastępczej z 9 czerwca 2011 r.). Na pieczę rodzinną składają się: rodzina zastępcza i rodzinny dom dziecka, zaś na instytucjonalną: placówki opiekuńczo-wychowawcze, regionalne placówki opiekuńczo-terapeutyczne, interwencyjne ośrodki preadopcyjne.

Dzieci wychowujące się w pieczy zastępczej czesto przejawiają trudności szkolne, co wynika, m.in. z: zaniedbań poznawczych, zaburzeń emocjonalnych utrudniających przyswajanie wiedzy, co z kolei wymusza konieczność utrzymywania wszechstronnych kontaktów z instytucjami edukacyjnymi, tj.: szkoła (pedagog szkolny, psycholog szkolny, wychowawcy, nauczyciele przedmiotowi, dyrektorzy szkół), poradnia psychologiczno-pedagogiczna, terapeuci i inni specjaliści. W sytuacji pobytu dziecka w pieczy zastępczej to wychowawca w placówce czy opiekun zastępczy przejmują role przypisane rodzicom.

Rodzina i szkoła to dla dziecka dwa podstawowe środowiska wychowawcze, mające decydujący wpływ na jego prawidłowy rozwój. Współdziałanie nauczycieli i rodziców decyduje o prawidłowym funkcjonowaniu dziecka w placówce edukacyjnej. Wpływa zarówno na jego postępy w nauce, jak i na zachowania. Krąg osób odpowiedzialnych za współ- pracę rodziny i szkoły jest dosyć szeroki, tworzą go rodzice, wychowawcy, dyrekcja szkoły, pedagog szkolny. Ale również często biorą w nim udział też inni członkowie rodziny - na przykład dziadkowie, także inni nauczyciele pracujący w szkole czy katechizujący księża (Opozda, 2009, s.144). Działania osób tworzących to środowisko powinny mieć charakter kompleksowy i integracyjny, „integracja będzie tu niezbędnym warunkiem skutecznego działania edukacyjnego, dydaktycznego, wychowawczego, opiekuńczego"(Winiarski, 2000, s.44).

Osoba pierwszego kontaktu rodzica ze szkoła jest oczywiście wychowawca, następnie nauczyciele przedmiotowi, aż wreszcie $\mathrm{w}$ razie potrzeby pedagog szkolny. Pedagog szkolny zatrudniony jest w celu uzupełnienia, pogłębienia i rozszerzenia działalności dydaktyczno-wychowawczej prowadzonej przez nauczycieli. Organizuje w szkole pomoc psychologiczno-pedagogiczną, nacisk kładzie na działania wychowawcze, opiekuńcze, diagnostyczno-doradcze (Matyjas, 2005, s.85).

Dodatkowo praca szkoły opiera się na współpracy z wieloma instytucjami, najważniejszą z nich jest poradnia psychologiczno-pedagogiczna. Oferuje ona pomoc psychologiczno-pedagogiczną dzieciom i młodzieży oraz ich rodzicom $w$ rozwiązywaniu problemów wychowawczych i edukacyjnych. Zadania poradni wynikają z Rozporządzenia MEN z dnia 1 lutego 2013 r. w sprawie szczegółowych zasad działania publicznych poradni psychologiczno-pedagogicznych, w tym publicznych poradni specjalistycznych. Wśród najważniejszych można wymienić: orzekanie $\mathrm{w}$ sprawie kształcenia specjalnego oraz $\mathrm{w}$ sprawach indywidualnego nauczania. Ponadto poradnia wydaje opinie potrzebne nauczycielom do dalszej pracy dydaktyczno-wychowawczej, w takich sprawach jak: wcześniejsze przyjęcie ucznia do szkoły lub odroczenia go; pozostawienia ucznia klas I-III drugi rok w tej samej klasie; dostosowania wymagań edukacyjnych do potrzeb ucznia z zaburzeniami i odchyleniami; udzielania zezwolenia na indywidualny program lub tok nauki i inne. Poradnia realizuje zadania poprzez diagnozowanie, terapię, konsultacje, doradztwo, rehabilitację, działalność profilaktyczną i informacyjną.

Zagadnienie współpracy rodziców z instytucjami edukacyjnymi można analizować pod kątem jej celowości, oczekiwań współuczestników, typów współpracy, jej uwarunkowań czy form (Lulek, 2012, s.31). Maria Mendel jako podstawowe formy współpracy tych dwóch środowisk wymienia, m.in.: utrzymywanie kontaktu z nauczycielami (w formie zebrań, rozmów indywidualnych, korespondencji); uczestnictwo we współorganizowaniu wycieczek, imprez klasowych i szkolnych; świadczenie usług na rzecz klasy, szkoły; uzgadnianie z nauczycielem wspólnego postępowania w stosunku do dziecka; wspólne diagnozowanie rozwoju dziecka; dzielenie się z nauczycielem wiedzą o nim (Mendel, 2000, s. 122).

Mikołaj Winiarski uważa, że współpraca rodziców i nauczycieli stanowi szczególną formę pomocy 
międzyludzkiej opartej na przekazywaniu informacji o dziecku, jego rodzinie i kontekście środowiskowym; świadczeniu różnych usług, np. poradnictwa czy doradztwa; podtrzymaniu emocjonalno-duchowym („udzielanie bliskości emocjonalnej” - okazywanie uczuć, przyjaźni, sympatii i in.) oraz dowartościowywaniu społecznym - przez wskazywanie zalet, wagi pełnionej roli, niezbędności w grupie, etc. (Winiarski, 2017, s. 292-293).

Warto również wspomnieć, iż badania Barbary Lulek dotyczące współpracy tych dwóch środowisk pozwalają na wyodrębnienie trzech kategorii szkół ze względu na rodzaje współpracy, tj::

a) Delegujący rodzaj współpracy - powoływanie rady rodziców jedynie jako organu pomocniczego mającego głównie udzielać szkole wsparcia w zakresie finansowo -materialnym, zaś nauczycielskie kontakty z rodzicami ogranicza się głównie do wywiadówek, rozmów indywidualnych, kontaktów telefonicznych, rodzic traktowany jest jako mniej kompetentny wychowawca.

b) Konsultacyjny rodzaj współpracy - rada rodziców podejmuje różnego rodzaju działania w zakresie wymiany informacji, aktywnego uczestnictwa w procesie dydaktyczno-wychowawczym, integracji społeczności szkolnej, rodzice biorą udział w opracowywaniu planu wychowawczego szkoły, współdecydują o sprawach wychowawczych i szkolnych.

c) Kooperacyjny rodzaj współpracy - względna równorzędność praw i obowiązków nauczycieli i rodziców we wszelkich działaniach dotyczących kształcenia i wychowania dzieci, możliwość partycypowania za pośrednictwem rady szkoły w procesie kierowania szkołą ( Lulek, 2008).

W przypadku kiedy dziecko przebywa w placówce opiekuńczo-wychowawczej, to wychowawcy pełnią te same role co rodzice biologiczni dziecka. Kwestie współpracy placówek opiekuńczo-wychowawczych $\mathrm{z}$ instytucjami edukacyjnymi reguluje, m.in. Ustawa z dnia 9 czerwca 2011 r. o wspieraniu rodziny i systemie pieczy zastępczej, w której możemy znaleźć zapisy dotyczące zapewnienia dziec$\mathrm{ku}$ dostępu do kształcenia dostosowanego do jego wieku i możliwości rozwojowych oraz objęcia go działaniami terapeutycznymi (art. 93). Ponadto bardziej szczegółowo zagadnienie współpracy wychowawców z instytucjami i osobami biorącymi udział w procesie wychowawczym i edukacyjnym dziecka określa Rozporządzenie Ministra Pracy i Polityki Społecznej z dnia 22 grudnia 2011 r. w sprawie instytucjonalnej pieczy zastępczej. Zgodnie z tym rozporządzeniem dla każdego dziecka prowadzi się, m.in.: kartę pobytu dziecka, która zawiera:

- informacje o przebiegu kontaktów placówki ze szkołą, do której dziecko uczęszcza, oraz jego nauki szkolnej;

- opis współpracy placówki z instytucjami i organizacjami działającymi na rzecz dziecka i rodziny, w tym $z$ asystentem rodziny.
Ponadto:

- kartę udziału w zajęciach prowadzonych przez psychologa, pedagoga lub osobę prowadzącą terapię, z opisem ich przebiegu, o ile dziecko tego wymaga;

- arkusze badań i obserwacji psychologicznych oraz pedagogicznych.

Dziecku umieszczonemu w placówce opiekuńczo-wychowawczej zapewnia się obok standardowego zaopatrzenia w podręczniki, pomoce, przybory szkolne, także dostęp do zajęć wychowawczych, kompensacyjnych, jak również terapeutycznych i rewalidacyjnych, o ile takie są wskazane dla dziecka.

\section{Materiał i metody}

Badania dla potrzeb niniejszej publikacji realizowano w Placówkach Opiekuńczo-Wychowawczych na terenie powiatu bialskiego. $W$ powiecie tym obecnie funkcjonują trzy placówki.

Placówka Opiekuńczo-Wychowawcza w Komarnie powstała 01.08.1997 r. Do 31.12.2012 r. funkcjonowała jako Dom Dziecka w Komarnie. Jest to placówka socjalizacyjna z 30 miejscami. Położona jest w gminie Konstantynów we wsi Komarno. Od roku 1999 organem prowadzącym jest Powiat Bialski. Placówka zapewnia całodobową opiekę i wychowanie dzieciom całkowicie lub częściowo pozbawionym opieki rodzicielskiej, dla których nie znaleziono rodzinnej opieki zastępczej. Zatrudnia ona 14 wychowawców. Obecnie w placówce przebywa 25 podopiecznych.

Tabela 1. Liczba dzieci przebywających w POW Komarno

\begin{tabular}{|c|c|c|}
\hline Wiek dzieci & Liczba dzieci & $\begin{array}{c}\text { Dzieci biorące } \\
\text { udział w badaniu }\end{array}$ \\
\hline Do 10 lat & 12 & \\
\hline 11-15 lat & 8 & 6 \\
\hline Pow. 15 lat & 5 & \\
\hline Łącznie & 25 & 6 \\
\hline
\end{tabular}

Kolejną placówką jest Placówka Opiekuńczo-Wychowawcza w Szachach. Funkcjonuje ona od 2003 r. Aktualnie jest jednostką organizacyjną podlegająca Centrum Administracyjnemu Placówek Opiekuńczo-Wychowawczych w Komarnie. Centrum odpowiada za obsługę ekonomiczno - administracyjną i organizacyjną prowadzonej placówki. Samodzielne mieszkanie przybliża mieszkańcom tego domu wzór mieszkania rodzinnego. POW w Szachach przeznaczona jest dla dzieci od 10 roku życia. Dysponuje ona 14 miejscami. Zatrudnia ona 5 wychowawców. W chwili obecnej przebywa w niej 10 podopiecznych. 
Tabela. 2 Liczba dzieci przebywających w POW Szachy

\begin{tabular}{|c|c|c|}
\hline Wiek dzieci & Liczba dzieci & $\begin{array}{c}\text { Dzieci biorące } \\
\text { udział w badaniu }\end{array}$ \\
\hline 11-15 lat & 2 & 2 \\
\hline Pow. 15 lat & 8 & 8 \\
\hline Łącznie & 10 & 10 \\
\hline
\end{tabular}

Ostatnią z trzech badanych placówek jest Placówka Opiekuńczo-Wychowawcza w Janowie Podlaskim. Rozpoczęła ona swą działalność 01.04.2010 r. Aktualnie jest jednostką organizacyjną podlegająca Centrum Administracyjnemu Placówek Opiekuńczo-Wychowawczych w Komarnie. Placówka powstała na bazie byłej strażnicy granicznej, budynek został dostosowany do obowiązujących standardów mieszkalnych dla 12 wychowanków. Z dziećmi pracuje 5 wychowawców. W placówce przebywa 10 podopiecznych.

Tabela 3. Liczba dzieci przebywających w POW Janów Podlaski

\begin{tabular}{|c|c|c|}
\hline Wiek dzieci & Liczba dzieci & $\begin{array}{c}\text { Dzieci biorące } \\
\text { udział w badaniu }\end{array}$ \\
\hline 11-15 lat & 3 & 3 \\
\hline Pow. 15 lat & 7 & 6 \\
\hline Łącznie & 10 & 9 \\
\hline
\end{tabular}

Badania o charakterze sondażowym zostały zrealizowane na niewielkiej próbie badawczej wśród 25 podopiecznych w/w placówek opiekuńczo-wychowawczych, w przedziale wiekowym 11 - 20 lat. Cała grupa w tej kategorii wiekowej liczyła 33 osoby, jednakże przebadanie większej liczby wychowanków było niemożliwe ze względu na fakt, iż spora grupa podopiecznych przebywa w Młodzieżowych Ośrodkach Socjoterapii, Młodzieżowych Ośrodkach Wychowawczych, realizuje proces kształcenia poza placówką bądź reprezentuje niższą kategorię wiekową. Zastosowaną techniką była ankieta zawierająca zarówno pytania zamknięte jak i otwarte.

Ponadto przeprowadzono 10 wywiadów z wybranymi wychowawcami tych trzech placówek. Wśród osób badanych byli zarówno mężczyźni jak i kobiety. Dodatkowo w ramach studium przypadku posiadane informacje uzupełniono rozmowami z koordynatorkami dwóch placówek.

Celem badań było ustalenie czy placówki opiekuńczo-wychowawcze współpracują z instytucjami edukacyjnymi, na czym ta współpraca polega, jakie przybiera formy? Ponadto autorów interesowało czy wymienione środowiska wychowawcze łączą wspólne cele, czy towarzyszy im rozbieżność oczekiwań? Jakie są uwarunkowania wzajemnych relacji?

Założono, że wychowawcy skutecznie zastępują rodziców w kwestiach dotyczących współpracy $\mathrm{z}$ instytucjami edukacyjnymi. Jednocześnie skon- centrowano się na analizie, takich czynników jak: usytuowanie placówki, ilość podopiecznych i ich wiek, płeć wychowawców i ich staż zawodowy.

\section{Wyniki}

Analizom poddano zarówno opinię podopiecznych placówek opiekuńczo-wychowawczych, jak i samych wychowawców oraz koordynatorów tych placówek. Skoncentrowano się w badaniach na kontaktach ze szkołami podopiecznych, bowiem pozostałe instytucje, tj.: poradnia psychologiczno-pedagogiczna, terapeuci, specjaliści pojawiają się w wypowiedziach respondentów sporadycznie i niejako przy okazji wyliczania form współpracy ze szkołą.

Podopiecznych zapytano, czy ich placówkowi wychowawcy utrzymują kontakty z wychowawcami i nauczycielami przedmiotowymi w szkole oraz poproszono o wskazanie form tych relacji. Wszyscy badani zgodnie stwierdzili, że kontakty te są realizowane. Jako formy kontaktu wskazano: wywiadówki oraz kontakty indywidualne $\mathrm{w}$ razie problemów. Za istotne można uznać fakt, że formę kontaktu indywidualnego wskazali podopieczni którzy uważaja, że źle się zachowuja oraz Ci którzy ukończyli 18 rok życia i dalej się kształcą, np. w liceach dla dorosłych. Płeć podopiecznych nie korelowała z wskazywanymi formami kontaktu ze szkołą. Do indywidualnych kontaktów z nauczycielami dochodziło częściej jeśli placówka i szkoła znajdowały się w jednej miejscowości oraz w przypadku gdy szkoła nie dysponowała dziennikiem elektronicznym, wówczas kontakt telefoniczny występował nawet codziennie "chociażby po to by sprawdzić czy wychowanek dotarł do szkoły”.

Wychowawcy wśród form współpracy wymieniają przede wszystkim różnego rodzaju kontakty z nauczycielami, tj.: wywiadówki, kontakt indywidualny, kontakt telefoniczny, mailowy, kontakt przez dziennik elektroniczny. W przypadku problemów stwarzanych przez podopiecznych na terenie szkoły spotkania obu stron odbywają się w miarę potrzeb, ich celem jest wypracowanie wspólnego stanowiska (niestety zdarza się to niezwykle rzadko). W razie konieczności korzysta się $\mathrm{z}$ pomocy szkolnych pedagogów (znacznie częściej problemy rozwiązuje pedagog szkolny bez udziału opiekuna $\mathrm{z}$ placówki). W skrajnych przypadkach „zdarzało się, że zbierała się rada pedagogiczna w szkole, na którą zapraszano opiekunów z placówki po to by wypracować sposoby postępowania z trudnymi wychowankami” (był tylko jeden taki przypadek na przestrzeni kilku ostatnich lat). W szkole „z problemowym wychowankiem pracuje pedagog szkolny, szczególnie w kwestiach dotyczących konfliktów rówieśniczych". Pedagodzy szkolni pomagają również w pisaniu opinii do sądu czy do Młodzieżowych Ośrodków Socjoterapii.

Inną formą współpracy tych dwóch środowisk wychowawczych jest uczestnictwo dyrektorów 
szkół, wychowawców klasowych i pedagogów szkolnych w posiedzeniach zespołu ds. okresowej oceny sytuacji dziecka, odbywających się na terenie placówki przynajmniej dwa razy w roku. Zadaniem zespołu jest, m.in.: analiza stosowanych metod pracy z dzieckiem, ocena jego aktualnych potrzeb czy modyfikowanie planu pomocy dziecku. Niestety w opinii respondentów zazwyczaj przedstawiciele szkolnego środowiska „są tylko biernymi słuchaczami, niezwykle rzadko angażują się w prace zespołu, chodzi raczej o to by zaznaczyć swoją obecność".

Z kolei udział „wychowawców placówkowych” w życiu szkoły przedstawia się bardzo różnie, nie zdarza się, np. aby opiekunowie z placówek byli zapraszani na dzień rodzica, niezwykle rzadko zapraszani są na imprezy szkolne, ale zdarza się, że proszeni są o pomoc w przygotowaniach do balu studniówkowego czy np. pomoc w przygotowaniu wigilii klasowej.

Reprezentantem opinii wszystkich rodziców jest Rada Rodziców wyłoniona $\mathrm{z}$ przedstawicieli rad klasowych wybieranych corocznie na początku roku szkolnego przez rodziców poszczególnych klas. Brak jakiegokolwiek wychowawcy w składzie tejże Rady oznacza brak wpływu na decyzje podejmowane w szkołach kształcących podopiecznych placówek opiekuńczo-wychowawczych. Może oczywiście to oznaczać brak zainteresowania opiekunów życiem szkoły, jednakże wynika raczej z faktu uczęszczania dzieci do różnych placówek edukacyjnych oraz nadmiaru innych obowiązków zawodowych.

Każdy wychowawca ma przydzielonych podopiecznych za których jest odpowiedzialny, również w kwestiach kontaktu ze szkołą. Niektórzy opiekunowie stwierdzają, że częściej angażują się w sprawy szkolne u tych dzieci, nad którymi sprawują opiekę prawną. Z analiz wynika, iż mężczyźni będący opiekunami rzadziej angażują się w życie szkolne swoich podopiecznych. Osoby z dużym stażem pracy w placówce częściej wykazują zaangażowanie w sprawy szkolne swoich wychowanków.

W każdej współpracy można doszukiwać się różnego rodzaju źródeł dezintegracji działań, które wg. Barbary Lulek mogą być wynikiem zaburzeń komunikacyjnych, różnych poglądów zaangażowanych jednostek, niewłaściwych relacji osobowych czy utrudnień w sferze materialnej (Lulek, 2012 , s.31-32).

W prezentowanych badaniach autorzy obserwują różnego rodzaju trudności we współpracy placówek opiekuńczo-wychowawczych z placówkami edukacyjnymi. Problemy te dotyczą m.in.: sfery materialnej i tu wymienia się: brak pedagoga szkolnego w niektórych szkołach wiejskich, brak specjalistów do pracy z dziećmi zaburzonymi czy niepełnosprawnymi. Problemy te wymieniane są najczęściej w małych środowiskach wiejskich, w których wychowawcy dostrzegają „niedostosowywanie wymagań edukacyjnych dla dzieci z obniżonymi możliwościami intelektualnymi".
Z kolei jako trudności natury komunikacyjnej wskazywane są: „rozbieżności oczekiwań ze strony nauczycieli i opiekunów z placówki”, „niechętna postawa nauczycieli w stosunku do uczniów sprawiających trudności”, „koncentrowanie się na złych zachowaniach ucznia, co powoduje uprzedzenia”, „często też nauczyciele nie próbują zrozumieć ucznia i jego problemów” ponadto „wykazują niechęć do pogłębionej diagnozy, do pomocy, do indywidualizacji w nauczaniu". Niejednokrotnie pojawił się także „problem z przepływem informacji i dokumentacji szkolnej ucznia”.

Niestety w niektórych szkołach (szczególnie w małych szkołach wiejskich) nagminna jest sytuacja, że opiekuna dziecka w ogóle nie wzywa się do szkoły lub dopiero w sytuacji, w której problem już funkcjonuje. W wielu miejscach „nie pracuje się z dzieckiem wychowawczo, stygmatyzuje się „dzieci placówkowe”, żąda się by z dzieckiem uczęszczać do lekarza psychiatry, podawać dzieciom leki psychotropowe, robi się wszystko by się dziecka pozbyć". Oczywiście jeśli jest taka możliwość placówka „unika umieszczania dzieci w tego typu instytucjach, w których dzieci są niechciane", jednakże usytuowanie placówek w małych środowiskach najczęściej wiejskich nie zawsze stwarza takie alternatywy. W ostateczności jednak „przenosi się dziecko do innej placówki” tak jest w przypadku tzw. trudnej młodzieży, dzieci te czują, że nauczyciele są do nich uprzedzeni i postrzegają ich naukę przez pryzmat problemów, które oni stwarzają w środowisku szkolnym".

\section{Wnioski}

1. Główne wskaźniki decydujące o występowaniu i formach współpracy POW ze szkołą wynikające z wypowiedzi podopiecznych to: wiek podopiecznych, zachowanie podopiecznych i problemy przez nich wskazywane oraz usytuowanie placówki przez nich zamieszkiwanej.

2. Z wypowiedzi dorosłych respondentów możemy wywnioskować, że środowisko w jakim znajduje się placówka ma zdecydowanie największy wpływ na jakość relacji pomiędzy opiekunami a nauczycielami, zdecydowanie gorzej wypadają małe środowiska wiejskie. Ponadto płeć wychowawców i staż pracy decydują o występowaniu bądź braku pewnych zachowań, jak np. angażowanie się w życie szkoły podopiecznego.

\section{Dyskusja}

Przedstawione $\mathrm{w}$ niniejszym opracowaniu rozważania oraz wyniki badań stanowią jedynie zarys problematyki związanej ze współpracą instytucji edukacyjnych z placówkami opiekuńczo-wychowawczymi. Jak wynika z analiz współpraca ta wygląda bardzo różnie, w niektórych szkołach jest na wysokim poziomie, w innych praktycznie nie występuje i niejednokrotnie wymusza zmiany środowiska szkolnego. 
Podkreślić należy, iż we współpracy z wymienianymi placówkami edukacyjnymi dominuje delegujący rodzaj współpracy, bowiem wśród form kontaktu wymienia się głównie: wywiadówki, kontakt indy widualny osobisty bądź telefoniczny, rzadkie uczestnictwo opiekunów w imprezach szkolnych bądź wychowawców klasowych w imprezach placówkowych, brak zaangażowania opiekunów w proces kształcenia i wychowawnia podejmowany w szkołach.

W sytuacji gdy różnego typu sprawy, problemy związane $\mathrm{z}$ funkcjonowaniem podopiecznych placówek opiekuńczo-wychowawczych w szkolnej społeczności, nie są konsultowane z ich opiekunami lub też gdy nie są wypracowywane wspólne rozwiązania pojawiają się liczne trudności na linii współpracy. Najważniejsze z nich to: nierozumienie problemów podopiecznych, uprzedzenia, stygmatyzowanie dzieci z placówki, niechęć do pogłębionej analizy ich problemów, brak podstawowej wiedzy co do pracy z uczniami sprawiającymi problemy wychowawcze, brak indywidualnego podejścia do problemowego ucznia, koncentrowanie się na negatywnych zachowaniach uczniów i ocenianie go przez ich pryzmat.

Powyżej wskazywane trudności we współpracy pomiędzy tymi dwoma środowiskami wychowawczymi potwierdzają, przynajmniej częściowo wyniki badań Ewy Marynowicz-Hetki i Jacka Piekarskiego, z których wynika, że szkoła i rodzina pozostają do siebie w opozycji, środowiska te wzajemnie się bardziej dystansują i zamykają, niż otwierają na współpracę ze sobą (Marynowicz-Hetka, Piekarski, 1995, s. 84-89).

\section{Literatura:}

1. Europejska Karta Praw i Obowiq̨zków Rodziców - Pobrane z: rodzicewedukacji.pl/europejska-karta-praw-i-obowiazkow-rodzicow/

2. Lulek, B. (2012). Nauczyciele i rodzice w szkole - razem czy osobno? Konteksty teoretyczne i perspektywa empiryczna. W: W. Błażejewski i in. (red.), Problemy przekazu wartości i komunikacji interpersonalnej we współczesnej szkole (s. 29-47). Jarosław: PWSTE.

3. Lulek, B. (2008). Współpraca szkoły, rodziny i środowiska. Rzeszów: Wydawnictwo Uniwersytetu Rzeszowskiego.

4. Marynowicz-Hetka, E., Piekarski, J. (1995). 0 wspólnocie wartości rodzinnych i szkolnych. W: A.W. Janke (red.), Pedagogiczna relacja rodzina-szkoła. Dylematy czasu przemian (s. 84-89). Bydgoszcz: WSP.

5. Matyjas, B. (2005). Pedagog szkolny. W: T. Pilch (red.), Encyklopedia Pedagogiczna XXI wieku, t. IV (s.85). Warszawa: Wydawnictwo Akademickie „Żak”.

6. Mendel, M. (2000). Rodzice i szkoła. Jak współuczestniczyć w edukacji dzieci. Toruń: Wydawnictwo Adam Marszałek.

7. Opozda, D. (2009). Współpraca rodziny i szkoły - o lepszą jakość relacji rodzice-nauczyciele. Paedagogia Christiana, 23(10), 137-145. https://doi.org/10.12775/PCh.2009.010

8. Rozporzadzenie Ministra Edukacji Narodowej z dnia 1 lutego 2013 r. w sprawie szczegółowych zasad działania publicznych poradni psychologiczno-pedagogicznych, $w$ tym publicznych poradni specjalistycznych - Dz. U. 2013, poz.199 z późn. zm.

9. Rozporządzenie Ministra Pracy i Polityki Społecznej z dnia 22 grudnia 2011 r. w sprawie instytucjonalnej pieczy zastępczej - Dz. U. Nr 292 poz. 1720.

10. Smykowska, D. (2008). Wspótpraca szkoły z rodzina w zaspokajaniu potrzeb rozwojowych dzieci z lekkim upośledzeniem umysłowym - działania stosowane i postulowane. Kraków: Wydawnictwo Impuls.

11. Ustawa o wspieraniu rodziny i systemie pieczy zastępczej z 9 czerwca 2011 roku - Dz. U. 2011, Nr 194, poz. 887 z późn. zm.

12. Winiarski, M. (2000). Rodzina - szkoła - środowisko lokalne. Aspekt socjopedagogiczny. Warszawa: Instytut Badań Edukacyjnych.

13. Winiarski, M. (2017). W kręgu pedagogiki społecznej. Studia - szkice - refleksje. Łódź - Warszawa: Społeczna Akademia Nauk. 